\title{
GULA KELAPA KRISTAL DAN POTENSI PEMANFAATANNYA PADA PRODUK MINUMAN
}

\author{
Nurul Fadhillah, Ervina Mela, dan Mustaufik \\ Program Studi Ilmu dan Teknologi Pangan, Jurusan Teknologi Pertanian, \\ Fakultas Pertanian, Universitas Jenderal Soedirman \\ Jl. Dr. Soeparno Karang Wangkal, Purwokerto 53151 \\ Email: ervina.mela@unsoed.ac.id
}

\begin{abstract}
Crystal coconut sugar is sugar that made from coconut sap which is processed to powder or crystal. This sugar has lower Glycemic Index and higher levels of fiber and vitamin B12 than cane sugar. Other advantages are that it is more soluble, has longer shelf life, more attractive in shape, easier to package and transport, has a unique taste and aroma, and can be fortified with other ingredients. Crystal coconut sugar can be used as a substitute for sugar cane in various beverage products. This paper aims to provide an overview of the process, excellence, and potential use of crystal coconut sugar in beverage products sourced from research journals and scientific books. Crystal coconut sugar has the potential to substitute cane sugar in tamarind syrup products, traditional drinks, instant powder drinks, instant chocolate drinks, coffee mixes, and ice cream.
\end{abstract}

Keywords: beverage products, crystal coconut sugar, potential uses

\section{PENDAHULUAN}

Gula merupakan suatu karbohidrat yang umumnya dihasilkan dari tebu atau dikenal sebagai gula pasir atau gula putih (pada tulisan ini selanjutnya ditulis sebagai gula tebu). Namun demikian, dari segi produksi, produsen gula tebu dalam negeri belum mampu memenuhi kebutuhan konsumsi dalam negeri, sehingga untuk menutupi kekurangan tersebut pemerintah melakukan impor gula. Impor gula ini pada kenyataannya terus meningkat dari tahun ke tahun sehingga membuat pemerintah khawatir karena merupakan ancaman terhadap kemandirian pangan. (El Fajrin, et al., 2015).

Selain itu dari segi bahan baku, diperkirakan akan terjadi kompetisi penggunaan bahan baku tebu yang semakin ketat di masa mendatang dengan semakin besarnya perhatian untuk memproduksi bioetanol dari tebu. Produksi dunia diperkirakan akan menurun sehingga pasokan dan stok gula dunia dapat terancam (Bantacut, 2016).

Salah satu satu produk pangan yang banyak menggunakan gula tebu adalah minuman. Hasil peramalan El Fajrin, et al. (2015) menunjukkan permintaan tebu dari industri minuman, makanan dan farmasi akan terus meningkat lebih kurang 202.526 ton pada tahun-tahun berikutnya. Seperti telah diuraikan sebelumnya, produksi gula tebu nasional belum mampu mencukupi seluruh permintaan industri sehingga untuk memenuhinya masih dibutuhkan gula impor. Salah satu upaya yang dapat dilakukan untuk menekan impor gula adalah dengan dengan mengganti gula tebu dengan gula kelapa kristal pada beberapa 
produk minuman. Hal ini didukung oleh pendapat Mustaufik dan Karseno (2004) yang menyatakan bahwa gula kelapa kristal dapat dijadikan substitusi gula tebu sebagai pemanis alami dan bahan baku minuman, campuran ramuan jamu dan lain-lain.

Tulisan ini bertujuan memberikan informasi mengenai cara pembuatan gula, keunggulan, dan pemanfaatan gula kelapa kristal pada berbagai produk minuman. Tulisan bersumber dari berbagai referensi berupa jurnal hasil penelitian dan buku-buku ilmiah. Harapannya, semakin banyak masyarakat Indonesia, baik perorangan maupun industri yang menggunakan gula kelapa kristal, sehingga manfaat dari gula kelapa kristal dapat semakin dirasakan oleh banyak pihak. Selain itu pemanfaatan gula kelapa kristal diharapkan menjadi salah satu alternatif untuk mengatasi keterbatasan produksi nasional gula tebu, menekan impor, dan memajukan industri gula palma khususnya gula kelapa kristal.

PEMBUATAN GULA KELAPA KRISTAL

Pembuatan gula kepala kristal relatif mudah dan menggunakan memerlukan peralatan yang sederhana (Abdullah, et al., 2014). Pada prinsipnya proses pembuatan gula kristal hampir sama dengan pembuatan gula cetak, hanya pada tahap akhir terdapat penambahan proses pembuatan serbuk. Menurut Mustaufik (2018), proses pembuatan gula kelapa kristal diawali dengan penyaringan nira menggunakan kain saring sehingga diperoleh nira yang bersih. Nira kelapa yang sudah dibersihkan kemudian dipanaskan menggunakan api sedang ketika nira sudah hampir mengental maka api dikecilkan.

Akhir pemasakan dapat diketahui secara visual, yaitu nira yang telah dipanaskan akan menggumpal (memadat dan mengeras) dan tidak bercampur dengan air jika dituang ke dalam air dingin. Cara lain adalah dengan menjatuhkan nira dari sendok atau garpu. Apabila jatuhnya membentuk benang-benang berarti titik akhir pemasakan sudah tercapai (Mustaufik, 2018). Langkah selanjutnya adalah kristalisasi (granulasi). Caranya, nira yang telah mengental didinginkan sambil dilakukan pengadukan untuk mendapatkan kristal-kristal gula (Pratama, et al., 2015). Gula kelapa kristal basah yang dihasilkan selanjutnya dikeringkan dengan oven pada suhu $60^{\circ} \mathrm{C}$ selama 60 menit.

Gula kristal kering yang telah jadi selanjutnya diayak dengan ayakan 20 mesh untuk memperoleh keseragam ukuran serbuk (Kartika, et al., 2017). Setelah produk terbentuk, maka proses terakhir dari pembuatan gula kelapa kristal adalah pengemasan. Pengemasan yang baik adalah dengan menggunakan plastik yang tahan panas dan kedap air serta tidak mudah rusak, adapun ukuran kemasan disesuikan dengan keadaan dan permintaan pasar (Kurniawan dan Bintoro, 2018).

\section{KEUNGGULAN GULA KELAPA KRISTAL}

Menurut Abdullah, et al. (2014) proses gula kelapa kristal tidak membutuhkan proses pemurnian dan pemutihan warna seperti halnya 
pada proses pembuatan gula tebu (gula pasir). Oleh karena itu dapat dikatakan bahwa keunggulan gula kelapa yang lain adalah bebas dari bahan kimia seperti flokulan, surfaktan, viscosity modifier, pemutih, pengawet dan GMO. Selain itu, karena pada proses produksi gula kelapa kristal relatif lebih singkat dan sederhana dibandingkan produksi gula pasir, maka gula kelapa kristal tidak kehilangan nutrisi penting di dalamnya yang antara lain vitamin, mineral dan protein, termasuk vitamin B12, yang sangat jarang ditemukan dari sumber

Tabel 1. Perbedaan antara gula kelapa kristal dan gula tebu

\begin{tabular}{lll}
\hline Perbedaan & Gula kelapa kristal & Gula tebu \\
\hline $\begin{array}{l}\text { 1. Sensori } \\
\text { a. Warna }\end{array}$ & Coklat & Putih kekuningan \\
b. Rasa & Kurang manis & Manis \\
c. Aroma & Harum khas & \\
2. Pembuatan & & \\
a. Proses & Lebih sederhana & Lebih kompleks \\
b. Pemutihan & Tidak ada & Ada \\
3. Indeks Glikemik & $35-44$ & $68-70$ \\
4. Total padatan terlarut & $95,7-97,3^{\circ}$ Brix & $92,5^{\circ}$ Brix \\
\hline
\end{tabular}

Sumber: Pertiwi (2015), Anggraeni (2019). Yulia dan Rahmi (2011)

Tabel 2. Komposisi kimia gula tebu, gula aren dan gula kelapa (per 100 gram)

\begin{tabular}{llll}
\hline Komponen & Gula Tebu & Gula Aren & Gula Kelapa \\
\hline Air & $5,4 \mathrm{~g}$ & $7,0 \mathrm{~g}$ & $10,0 \mathrm{~g}$ \\
Energi & $394 \mathrm{Kal}$ & $368 \mathrm{Kal}$ & $386 \mathrm{Kal}$ \\
Protein & $0,0 \mathrm{~g}$ & $0,0 \mathrm{~g}$ & $3,0 \mathrm{~g}$ \\
Lemak & $0,0 \mathrm{~g}$ & $0,0 \mathrm{~g}$ & $10,0 \mathrm{~g}$ \\
Karbohidrat & $94,0 \mathrm{~g}$ & $92,0 \mathrm{~g}$ & $76,0 \mathrm{~g}$ \\
\hline
\end{tabular}

Sumber: Kemenkes (2018)

Selain dari bentuk fisik, proses produksi Indeks Glikemik (IG). Nilai IG merupakan gula kelapa kristal juga unggul dalam nilai indikator seberapa cepat bahan pangan jenis 
karbohidrat terurai dalam pencernaan dan melepaskan kandungan glukosanya ke dalam aliran darah. Pada penelitian Pertiwi (2015) dijelaskan bahwa nilai IG gula tebu berkisar antara 68-70, sedangkan nilai IG gula kelapa kristal antara 35-44 atau termasuk golongan IG rendah. Keunggulan lainnya adalah gula kelapa kristal lebih mudah larut, daya simpan lebih lama, bentuknya lebih menarik, lebih memudahkan dalam pengemasan dan pengangkutan, rasa dan aromanya lebih khas dan dapat difortifikasi atau diperkaya dengan bahan lain seperti Yodium, vitamin A atau mineral lainnya (Mustaufik, 2018).

Keunggulan lain dari gula kelapa kristal adalah bentuknya yang berupa serbuk sehingga menyebabkan gula mudah larut sehingga praktis dalam penyajian, mudah dikemas dan dibawa, serta memiliki daya simpan yang lebih lama karena kadar air yang rendah dibandingkan dengan gula cetak (Zuliana, et al., 2016). Selain berfungsi sebagai pemanis alami (Abdullah, et al., 2014), gula kelapa juga berfungsi sebagai pemberi warna coklat (Pertiwi, 2015).

\section{POTENSI PEMANFAATAN GULA KELAPA KRISTAL PADA PRODUK MINUMAN}

\section{Sirup Asam Jawa}

Sirup asam jawa merupakan bentuk larutan inti untuk minuman dengan rasa buah asam yang asli, penyajiannya harus diencerkan terlebih dahulu dengan air. Pada penelitian Dirhamsyah dan Nurhaida (2018) bahan yang digunakan adalah buah asam jawa yang sudah matang 500 gram, air bersih 3 liter, dan gula tebu 3 kilogram.

Sirup asam jawa selain rasanya yang segar juga berkhasiat dalam mengatasi flu, demam, gangguan pada perut, diare, jaundice atau kuning dan sebagai pembersih kulit (Doughari, 2006). Untuk menunjang khasiat tersebut maka pada pembuatan sirup asam sebagai minuman fungsional lebih baik digunakan gula kelapa kristal yang ternyata mengandung antioksidan. Hal ini berhubungan dengan bahan pembuat gula kelapa kristal yaitu nira kelapa. Nira kelapa sebagai bahan baku gula kelapa kristal diketahui mengandung sukrosa, gula pereduksi dan protein. Terbentuknya warna cokelat pada gula hasil pemasakan, merupakan Reaksi Maillard yang dapat menghasilkan senyawa yang bersifat sebagai antioksidan (Septiana dan Dwiyanti, 2014).

\section{Minuman Tradisional}

Yang dimaksud dengan minuman tradisional yaitu wedang ronde, wedang uwuh, bir pletok, bandrek dan bajigur. Wedang Ronde merupakan minuman khas daerah Jawa Tengah. Minuman ini dibuat dari sari jahe yang hangat dengan isian beragam. Wedang ronde biasanya dihidangkan dengan isian moci atau ketan bulat, kolang - kaling, roti tawar, agaragar, dan sebagainya. Wedang ronde memiliki rasa yang manis dan pedas. Rasa manis dari minuman ini didapatkan dari campuran gula dan pedas dari perasan jahe sendiri (Lestari, et al., 2018). 
Adapun wedang uwuh adalah minuman dengan bahan-bahan yang berupa dedaunan mirip dengan sampah. Dalam bahasa Jawa, wedang berarti minuman, sedangkan uwuh berarti sampah. Wedang uwuh disajikan panas atau hangat memiliki rasa manis dan pedas dengan warna merah cerah dan aroma harum. Rasa pedas karena bahan jahe, sedangkan warna merah karena adanya secang. Wedang uwuh ini adalah minuman khas dari Yogyakarta (Hartati dan Suryaningsum, 2019). Pada penelitian Herdiana, et al. (2014) bahan yang digunakan adalah 320 gram jahe, 15,18 gram daun cengkeh, 63,40 gram ranting cengkeh, 13,39 gram daun kayu manis, 15,46 gram daun pandan, 40,77 gram serutan secang, 566,8 gram gula batu, $520 \mathrm{ml}$ air seduh gula, dan $2.900 \mathrm{ml}$ air seduh uwuh.

Sedangkan bir pletok merupakan minuman tradisional khas dari DKI Jakarta atau biasa disebut asli betawi. Minuman ini banyak memiliki khasiat yang sangat baik untuk tubuh karena dapat menghangatkan dan memperlancar aliran darah. Bahan-bahan yang digunakan untuk pembuatan minuman ini yaitu gula tebu dan rempah-rempah yang sering digunakan pada kehidupan sehari-hari, seperti jahe, daun pandan, serai, kayu manis, cengkeh dan kayu secang. Tambahan kayu secang membuat minuman ini menjadi merah atau berwarna kecoklatan ketika diseduh dengan air panas dan mampu menarik perhatian penggemar minuman (Sabila, 2017). Hal ini didukung oleh penelitian (Ishartani, et al.,
2012) yang menemukan bahwa formula sirup bir pletok dengan pewarna secang dan pemanis gula merah, nilai penerimaan konsumen atas rasa, warna, aroma, lebih tinggi dibanding formula yang menggunakan pemanis gula tebu (Ishartani, et al., 2012).

Selain itu ada pula bandrek, yaitu minuman tradisional orang Sunda (Jawa Barat), yang dikonsumsi untuk meningkatkan kehangatan tubuh. Minuman ini biasanya dihidangkan pada cuaca dingin, seperti di kala hujan ataupun malam hari. Bahan dasar bandrek yang paling penting adalah jahe dan gula merah, tetapi pada daerah tertentu biasanya menambahkan rempah-rempah tersendiri untuk memperkuat efek hangat yang diberikan bandrek, seperti serai, merica, daun pandan, telur ayam kampung, dan sebagainya (Suhartanti, 2009). Pada penelitian Sutrisno, et al. (2018) bahan yang digunakan adalah 300 gram jahe merah, 1 kilogram gula tebu, 100 gram irisan gula merah, 2 lembar daun pandan, 1 ruas kayu manis, dan 1 batang serai. Produk minuman selanjutnya adalah Bajigur. Bajigur juga merupakan minuman tradisional khas masyarakat Sunda. Pada penelitian Amalia, et al. (2015) bahan yang digunakan adalah santan, air secukupnya, 250 gram gula merah, $100 \mathrm{~g}$ jahe, 3 helai daun pandan dan 240 gram gula tebu. Gula tebu yang digunakan pada pembuatan minuman tradisional ini dapat digantikan dengan gula kelapa kristal. 


\section{Serbuk Minuman Tradisional}

Mulai merebaknya pola hidup back to nature di masyarakat dengan mengonsumsi bahan-bahan alami, membuka peluang pengembangan produk rimpang Spesies Zingiberaceae seperti jahe, kunyit, kunyit putih dan temulawak, yang mengandung antioksidan (Septiana, et al., 2014). Namun demikian konsumen umumnya menginginkan produk yang praktis dan siap konsumsi. Oleh sebab itulah serbuk minuman tradisonal berbahan dasar rimpang mulai banyak digemari.

Serbuk minuman jahe dan minuman temulawak instan digolongkan dalam minuman fungsional, karena bahan baku yang digunakan mengandung satu atau lebih senyawa yang dianggap mempunyai fungsi-fungsi fisiologis tertentu yang bermanfaat bagi kesehatan. Minuman serbuk instan yang baik harus mudah larut dalam air dingin atau panas. Penggunaan gula kelapa kristal sangat cocok untuk bahan baku serbuk minuman instant karena menurut Purnomo dan Setiaji (2011) gula kelapa kristal memiliki tekstur bubuk sehingga kadar kelarutannya sangat tinggi, bahkan bisa larut pada suhu air normal, selain itu gula kelapa kristal juga mempunyai aroma yang khas dan harum. Hal ini juga didukung oleh penelitian Kawiji dan Ariviani (2016), yang menemukan bahwa penggunaan gula kelapa pada pembuatan ekstrak temulawak menghasilkan aktivitas antioksidan tertinggi dibanding gula tebu.

\section{Minuman cokelat instan}

Minuman cokelat adalah minuman olahan dari cokelat, yang biasanya berbentuk bubuk. Minuman cokelat susu terbuat dari campuran gula, kakao, cokelat cair, susu, dan vanila. Olahan cokelat inilah yang paling banyak dikonsumsi. Masa kakaonya cukup tinggi, sekitar 80 persen dan rasanya lebih manis (Nurhidayah, 2014). Pada penelitian Rosniati (2016) bahan yang digunakan adalah kakao bubuk, susu kedelai bubuk, gula dan krimmer.

Sama halnya dalam pembuatan minuman instan lainnya, penggunaan gula tebu dapat digantikan dengan gula kelapa kristal. Hal ini dikarenakan gula kelapa kristal memiliki tekstur serbuk sehingga mudah dalam proses pelarutan. Permata dan Sayuti (2016) menyatakan bahwa kelarutan menjadi salah satu aspek penting pada mutu minuman serbuk instan. Oleh karena itu penggunaan gula kelapa kristal cocok untuk digunakan pada minuman instant gula kelapa kristal karena memiliki tekstur bubuk sehingga kadar kelarutannya sangat tinggi, bahkan bisa larut pada suhu air normal (Purnomo dan Setiaji, 2011)

\section{Kopi mix instant gula kelapa}

Kopi mix instan adalah biji kopi yang sudah diproses dan digiling halus dalam bentuk butiran-butiran kecil sehingga mudah diseduh dengan air panas dan dikonsumsi (Grace, 2017). Adapun kopi mix instant gula kelapa, merupakan minuman kopi instan yang dibuat 
melalui modifikasi penambahan gula kelapa kristal (Widya, 2019).

Pengolahan kopi dengan gula palma sebenarnya bukan hal yang baru. Hal ini telah terjadi sejak lama dan menjadi kebiasaan pada sebagian masyarakat yang menikmati kopi Mandailing, Kopi ini diseduh dengan rebusan air aren. Hasil seduhan menghasilkan aroma kopi yang kuat dan khas (Gumulya dan Helmi, 2017). Hal ini didukung oleh penelitian Praptiningsih dan Wijayanti (2012) yang menggunakan gula kelapa kristal pada pembuatan kopi instant dengan pertimbangan bahwa gula kelapa mempunyai cita rasa khas, sehingga apabila digunakan dalam pembuatan kopi instant dapat meningkatkan cita rasa kopi yang dihasilkan. Oleh karena itu pengolahan kopi menjadi produk kopi mix gula kelapa dengan menggunakan gula kelapa kristal merupakan sesuatu yang potensial untuk dikembangkan.

\section{Es krim}

Es krim merupakan salah satu jenis makanan berbentuk beku dengan tekstur yang lembut dan memiliki nilai gizi tinggi serta merupakan makanan yang digemari oleh berbagai golongan masyarakat. Es krim adalah salah satu produk makanan beku yang dibuat dengan membekukan campuran produk susu, gula, penstabil, pengemulsi dan bahan-bahan lainnya yang telah dipasteurisasi dan dihomogenisasi untuk memperoleh konsistensi yang seragam (Clarke, 2015).
Menurut Clarke (2015) tidak ada aturan baku bahwa dalam pembuatan es krim harus digunakan gula tebu. Hal ini menyebabkan komposisi es krim bervariasi di berbagai negara tergantung pada bahan baku yang tersedia. Oleh karena itu gula kelapa kristal dapat dijadikan sebagai pemanis pada produk es krim. Penggunaan gula kristal akan menambah nilai tambah produk es krim, sehubungan dengan kandungan serat yang lebih tinggi (Kemenkes, 2018) dan IG yang lebih rendah dari gula tebu. Penggunaan gula kelapa kristal cocok digunakan pada produk es krim yang diperuntukkan bagi anak-anak, karena gula ini tidak akan menimbulkan gejala hiperaktif pada anak-anak (Abdullah, et al., 2014).

\section{KESIMPULAN}

Gula kelapa kristal merupakan gula yang proses pembuatannya relatif sederhana tanpa menggunakan bahan-bahan kimia tambahan. Gula ini memiliki keunggulan berupa nilai Indeks Glikemik yang lebih rendah dari gula tebu namun kadar serat dan vitamin B12 yang lebih tinggi dari gula tebu. Gula kelapa kristal berpotensi dimanfaatkan pada pembuatan produk sirup asam jawa, minuman tradisional, minuman serbuk instant, minuman coklat instan, kopi mix instant dan es krim.

\section{UCAPAN TERIMA KASIH}

Terima kasih kepada Lembaga Penelitian dan Pengabdian Kepada Masyarakat Universitas Jenderal Soedirman yang telah membiayai penelitian ini melalui Skim Riset Kompetensi BLU Unsoed Tahun 2019. 


\section{DAFTAR PUSTAKA}

Abdullah, W. G., U. Rianse, R. M. Iswandi, S. A. A. Taridala, W. Widayati, I. S. Rianse, L. R. Baka dan W. K. Baka. 2014. Potency of natural sweetener: Brown sugar. Advances in Environmental Biology. 12(1):374-386.

Amalia, R., H. Nurul, A. Abraham, B. Prima dan A. Siti. 2015. Pengaruh Penambahan Variasi Gula Pasir Terhadap Waktu Kristalisasi dan Karakteristik Organoleptik Bajigur Instan. Laporan Penelitian. Universitas Jember.

Anggraeni, T. I. 2019. Pengaruh Konsentrasi Ekstrak Kayu Manis (Cinnamomum Burmannii) dan Konsentrasi Gula Semut Terhadap Karakteristik Minuman Sari Buah Jambu Mete (Anacardium Occidentale). Skripsi. Universitas Pasundan.

Bantacut, T. 2016. Swasembada gula: prospek dan strategi pencapaiannya. Jurnal Pangan. 19(3):245-256.

Clarke, C. 2015. The science of ice cream. Royal Society of Chemistry. 201 p.

Dirhamsyah, M. dan N. Nurhaida. 2018. Pembuatan sirup asam jawa (Tamarindus Indica L.) sebagai salah satu usaha diversifikasi pangan untuk minuman kesehatan di desa bintang mas kecamatan rasau jaya kabupaten kubu raya. Jurnal Pengabdi. 1(1):1-6.

Doughari, J. 2006. Antimicrobial activity of Tamarindus indica Linn. Tropical Journal of Pharmaceutical Research. 5(2):597603.

El Fajrin, A., S. Hartono dan L. R. Waluyati. 2015. Permintaan Gula Rafinasi Pada Industri Makanan Minuman Dan Farmasi Di Indonesia. Agro Ekonomi. 26(2):150158.

Grace, H. A. 2017. Invertarisasi Organoleptik, Kandungan Kafein, dan Asam Klorogenat pada Kopi Bubuk Robusta (Coffea canephora L) di Kabupaten Tanggamus. Skripsi. Universitas Lampung.

Gumulya, D. dan I. S. Helmi. 2017. Kajian budaya minum kopi indonesia. Jurnal
Dimensi Seni Rupa dan Desain. 13(2):153-172.

Hartati, A. S. dan S. Suryaningsum. 2019. Pengadaan usaha wedang uwuh dengan pemberdayaan ibu rumah tangga sebagai pengentas kemiskinan. Jurnal Manajemen Dayasaing. 21(1):24-31.

Herdiana, D. D., R. Utami dan R. B. K. Anandito. 2014. Kinetika degradasi termal aktivitas antioksidan pada minuman tradisional wedang uwuh siap minum. Jurnal Teknosains Pangan. 3(3):44-53.

Ishartani, D., K. Kawiji dan L. U. Khasanah. 2012. Produksi Bir Pletok Kaya Antioksidan. Jurnal Teknologi Hasil Pertanian. 5(1):1-8.

Kartika, A. M., A. M. Legowo dan S. Etza. 2017. Pengaruh Penambahan Ekstrak Bunga Kecombrang (Etlingera etlatior) Terhadap Sifat Fisikokimia Gula Semut Kelapa. Skripsi. Universitas Diponogoro.

Kawiji dan S. Ariviani 2016. Antioxidant capacity of temulawak drink (Curcuma xanthorrhiza) with white crystal sugar cane, red crystal sugar cane, palm sugar, and arenga palm sugar. Biofarmasi Journal of Natural Product Biochemistry. $14(2): 39-46$.

Kemenkes. 2018. Data Komposisi Pangan Indonesia. http://www.panganku.org. 27 September 2019.

Kurniawan, H. dan N. Bintoro. 2018. Pendugaan umur simpan gula semut dalam kemasan dengan pendekatan arrhenius (shelf life prediction of palm sugar on packaging using Arrhenius equation). Jurnal Ilmiah Rekayasa Pertanian dan Biosistem. 6(1):93-99.

Lestari, L. A., P. M. Lestari dan F. A. Utami. 2018. Kandungan zat gizi makanan khas Yogyakarta. Yogyakarta:UGM PRESS. $175 \mathrm{p}$.

Mustaufik. 2018. Peningkatan Mutu Produksi dan Pemasaran Gula Semut Beriodium di Koperasi Serba Usaha (KSU) Ligasirem Sumbang-Banyumas. Performance. 19(1):68-84.

Nurhidayah, M. 2014. Pengaruh Konsentrasi Susu Sapi Segar Dan Konsentrasi Dekstrin Terhadap Mutu Minuman 
Cokelat Instan. Skripsi. Universitas Sumatera Utara.

Permata, D. A. dan K. Sayuti. 2016. Pembuatan Minuman Serbuk Instan dari Berbagai Bagian Tanaman Meniran (Phyllanthus niruri). Jurnal Teknologi Pertanian Andalas. 20(1):44-49.

Pertiwi, P. 2015. Studi Preferensi Konsumen Terhadap Gula Semut Kelapa di Universitas Lampung. Skripsi. Universitas Lampung.

Praptiningsih, Y. dan S. Wijayanti. 2012. SifatSifat Kopi Instan Gula Kelapa dari Berbagai Rasio Kopi Robusta-Arabika dan Gula Kelapa-Gula Pasir. Jurnal Agroteknologi. 6(01):70-77.

Pratama, F., W. H. Susanto dan I. Purwantiningrum. 2015. Pembuatan Gula Kelapa dari Nira Terfermentasi Alami (Kajian Pengaruh Konsentrasi Anti Inversi dan Natrium Metabisulfit). Jurnal Pangan dan Agroindustri. 3(4):12721282.

Purnomo, M. J. dan A. B. Setiaji. 2011. Optimasi Alat Penepung Gula Kristal Hasil Granulasi Menggunakan Mesin Hammer Mill pada Sistem Pembuatan Gula Semut. Disertasi. Universitas Gadjah Mada.

Rosniati, R. 2016. Pengembangan minuman instan cokelat-kedelai sebagai minuman kesehatan. Jurnal Industri Hasil Perkebunan. 11(1):33-42.

Sabila, A. 2017. Upaya Pelestarian Minuman Tradisional Bir Pletok Khas Betawi. Skripsi. Universitas Pendidikan Indonesia. Septiana, A. T. dan H. Dwiyanti. 2014. Aktivitas antioksidan minuman fungsional dari irisan buah kering mahkota dewa. agriTECH. 29(1):16-21.
Septiana, A. T., Mustaufik dan M. Samsi. Year. Pengaruh Jenis Rempah, Jenis Gula Dan Bentuk Minuman Terhadap Kapasitas Penangkapan Radikal Bebas Dari Minuman Kunyit Asam. Dalam Seminar Nasional Pengembangan Sumber Daya Perdesaan dan Kearifan Lokal Berkelanjutan IV, Purwokerto, 20-21 November 2019. hlm 53-61.

Suhartanti, R. E. 2009. Analisis Pengendalian Persediaan Bahan Baku Minuman Bandrek Pada Cv. Cihanjuang Inti Teknik. Skripsi. UIN Syarif Hidayatullah.

Sutrisno, D., D. Sagita, S. Hamidatul'Aliyah, Y. Yuliawati, L. Andriani, L. Anggresani, B. Hartesi, S. Perawati, R. Rozalti dan H. Murtiah. 2018. Pemberdayaan masyarakat melalui peningkatan nilai produk bandrek jahe di kelurahan sijinjang Kota Jambi. LOGISTA-Jurnal Ilmiah Pengabdian kepada Masyarakat. 2(1):31-36.

Widya, F. 2019. Karakteristik Fisikokimia dan Sensoris Kopi Mix Gula Kelapa dari Berbagai IKM dengan Variasi Lama Penyimpanan. Skripsi. Universitas Jenderal Soedirman.

Yulia, A. dan S. L. Rahmi. 2011. Studi pembuatan minuman kayu manis berkarbonasi dengan penambahan gula pasir dan natrium bikarbonat. Jurnal Penelitian Universitas Jambi: Seri Sains. 13(1):53-59.

Zuliana, C., E. Widyastuti dan W. H. Susanto. 2016. Pembuatan Gula Semut Kelapa (Kajian pH Gula Kelapa Dan Konsentrasi Natrium Bikarbonat). Jurnal Pangan dan Agroindustri. 4(1):109-119. 